DOI: $10.19195 / 0137-1150.163 .36$

\author{
KLAUDIA KOCZUR-LEJK \\ Uniwersytet Szczeciński, Polska \\ klkoczur@wp.pl
}

\title{
Starość jako etap życia w dziele Bartłomieja Paprockiego Trínácte tabulí věku lidského
}

Bartłomiej Paprocki (1543-1614) to pisarz, któremu przypisuje się największe zasługi dla przenikania literatury polskiej do Czech na przełomie wieków XVI i XVII. Pisał dzieła genealogiczne, wiersze okolicznościowe, satyry, panegiryki, pamflety, polemiki religijne $\mathrm{i}$ inne.

W roku 1588, po bitwie pod Byczyną, w której porażkę poniósł habsburski pretendent do tronu polskiego, Paprocki jako jego stronnik był zmuszony do opuszczenia ojczyzny. Emigrował na ziemie Korony Czeskiej, gdzie kontynuował rozpoczętą w Polsce działalność literacką. W języku czeskim pisarz wydał 26 pozycji, wśród których znalazły się przeróbki jego wcześniejszych utworów polskich.

Problematyka starości w bogatej twórczości Bartłomieja Paprockiego realizowana jest na wielu płaszczyznach $\mathrm{w}$ wielorakich kontekstach i różnych znaczeniach.

W swoich czeskich dialogach polemicznych ${ }^{1}$, jak również w przedmowie do dzieła Kvalt na pohany ${ }^{2}$, pisarz utożsamia starość z dziedzictwem narodowym, tradycją przodków i wartościami, jakim hołdowali Czesi od wieków. Przypomina czeskie dzieje, fakt, iż kraj niegdyś był katolicki z wiary i chrześcijańskiego obyczaju, w tym świetle innowiercy stają się burzycielami starego porządku, a wyznanie

${ }^{1}$ B. Paprocký, Rozmlouvání kolátora s farářem velmi pěkné, každému křestianskému člověku užítečné. Nyní v nově sepsané a vydané, v Brně u Bartoloměje Albrechta Formana, 1607; B. Paprocký, Štambuch slezský, v kterém hospodař s hostem o mnohých věcech spasitedlných rozpravuji, pod erby a rody starodavných pánuv, pánuv a rytírstva knižetstvi hornich v Slezí, v Brně u Bartoloměje Albrechta Formana, 1607.

${ }^{2}$ B. Paprocký, Kvalt na pohany ke všem křestanským panům, králům i knižatům a zvláště nejpřmoženějšiho královstvi polského obojím stavi̊m duchovnímu i světskému učiněný, bez miejsca wydania 1595. 
protestanckie jawi się jako coś nowego i nieczeskiego, co należy odrzucić i wrócić do poprzedniego stanu. Paprocki wysuwa tezę o starszeństwie katolicyzmu, jego dawnym pochodzeniu, co miało stanowić istotny czynnik kształtowania u odbiorców postawy emocjonalnego przywiązania. Swe wywody opiera na autorytecie ludzi starych, będących przekazicielami dziedzictwa poprzednich pokoleń i gwarantami autentyczności przekazywanych przez niego treści ${ }^{3}$.

Motyw starości w kontekście odwiecznego konfliktu rodziców z dziećmi zawarł Paprocki w satyrze Testament starca jednego 4 i jej czeskiej prozatorskiej przeróbce Kšaft, jenž byl od jednoho starce učiněn ${ }^{5}$. Autor kreśli tu obraz starego człowieka - ojca, który mimo usilnych starań nie zdołał nakłonić swych trzech synów do życia w cnocie (jeden jest pijakiem, drugi hazardzistą, trzeci rozpustnikiem). Na łożu śmierci chce ich pouczyć i przykładnie skarcić. Za najbardziej odpowiednią karę uznał pozbawienie prawa do majątku tego syna, który dopuścił się największych przestępstw. Autor porusza problematykę odchodzenia, szykowania się na śmierć w powiązaniu z koniecznością uporządkowania spraw majątkowych i relacji rodzinnych.

Inna odsłona starości u Paprockiego to topos podstarzałej kobiety, nieatrakcyjnej, zalotnej kokietki, jaki występuje w Novej kratochvilit ${ }^{6}$ oraz w Pannie ${ }^{7}$. Paprocki drwi ze starych wdów, które nie potrafią pogodzić się z upływem czasu, stosują różne zabiegi upiększające, by wyglądać młodo i znaleźć kolejnego męża ${ }^{8}$. Wyśmiewa też związki małżeńskie zawierane z powodów finansowych, w których partnerów dzieli duża różnica wieku.

I wreszcie, starość jako finalna faza ziemskiego istnienia człowieka w dziele Třinácte tabulí věku lidského ${ }^{9}$. Paprocki w formie popularnego speculum prezentuje czytelnikowi powinności i rady właściwe poszczególnym etapom ludzkiego

${ }^{3}$ Por. K. Koczur-Lejk, Bartlomiej Paprocki - piśmiennictwo i przekład. W stronę kontrreformacji, Szczecin 2014, s. 222.

${ }^{4}$ B. Paprocký, Testament starca jednego, który miat trzech synów: z których jeden pijaństwem, drugi nierządna miłościa, trzeci się kosterstwem bawił. Tych nie mogąc już w niemocy inaczej skarać, rozkazat, aby gorszy z nich $w$ dobrach jego po śmierci nie dziedziczyt. Nowo z łacińskiego języka na polski przełożony, w Krakowie u Mateusza Siebeneychera, 1578.

${ }^{5}$ B. Paprocký, Kšaft, jenž byl od jednoho starce učiněn třem synům nepořádně se chovajicím tak aby nejhorši z nich v statku jeho nedědil. Pročež oni dali se v soud, jedenkaždý, aby dédicem zůstal po otci, skutky své schvalujic a druhého zlehčujic. Z čeho jedenkaždý naučit se müže, jak se má vystřihat marnosti, v Praze u J. Šumana 1601.

${ }^{6}$ B. Paprocký, Jiná částka nové kratochvíle, s kterouž bohyně Venus na svět vyšla, pět set žertův i jiných kratochvilných př́kladi̊v s sebou vede. Z rozličných přiběhưv sebrané a nově vydané, v Starém Městě pražském u Daniele Sedlčanského, 1598.

${ }^{7}$ B. Paprocký, Panna, v Starém Městě pražském u Jana Šumana, 1602.

${ }^{8}$ Por. wiersz K jedné staré vdově řeč: „Nečiň se, má jest rada, stará paní mladou/ Neb to bude tomu věř s velikou tvou škodou/ Nastudíš sobě hlavu tím čepcem př́íkrytou/ Každý se z tvé čerstvosti té neslušné směje/ Řkouc zadek odmlazuješ, hlavat’ šedivěje”, [w:] B. Paprocký, Jiná částka nové kratochvile..., k. L3 v.

${ }^{9}$ B. Paprocký, Třinácte tabuli věku lidského krátce sepsaných, v Starém Městě pražském u Jana Šumana, 1601. 
życia, których doświadczy każdy, kto dożyje sędziwego wieku. Jednocześnie ma go prowadzić do osiągnięcia wiecznego szczęścia w Królestwie Niebieskim. Na karcie tytułowej autor zawarł łacińskie motto z Cycerona: Hominis Vita brevis est, gloriae cursus sempiternus (Życie jest krótkie - chwała nieśmiertelna), wskazujące na to, że wobec wieczności życie to jedynie drobny epizod, natomiast pamięć o człowieku trwa znacznie dłużej, szczególnie jeśli jest chwalebna, gwarantuje nieśmiertelność. A zatem, gdy ktoś chce być nieśmiertelny, powinien zapewnić sobie za życia chwałę, która będzie trwała zawsze. Utwór zadedykowany Karolowi I Liechtensteinowi Paprocki opatrzył drzeworytem herbowym oraz wierszem na herb. Następnie w przedmowie zawarł główne idee rozwijane konsekwentnie w dalszej części utworu: myśl przewodnią księgi Koheleta — wszystko to marność (omnia vanitas) oraz motyw alegorycznej pielgrzymki życia (pelegrinatio vitea):

Patříc na široké strany světa tohoto, milostivý pane, nemohu na něm nic jiného spatřiti, jednom marnost samou. [...] Ale že to jest vůle Božská, abychom tu peregrinaci v něm vykonali, potřebí nám usilovat o to, abychom vedle vůle jeho svaté, do kavád nás na něm chovat ráčí, poctivě a náležitě živi byli. Jak tehdy na ten svět přicházíme, jak na něm putujíc živi býti máme, krátce to nám mužův oněch vznešených písma a naučení jich oznamuji $1^{10}$.

Te elementy, jak również widoczna rezygnacja z dóbr doczesnych, zwrot ku wieczności, a także styl retoryczny i fascynacja tematyką śmierci widoczne w drugiej części dzieła pozwoliły badaczom czeskim uznać utwór za dzieło manierystyczne ${ }^{11}$.

Każdy człowiek jest podmiotem doświadczającym upływu czasu, a zarazem biernym przedmiotem tegoż doświadczania. Czas antropologiczny, czyli miara temporalna odnosząca się do życia ludzkiego, jest kategorią złożoną, mieszczącą w sobie takie aspekty, jak: czas biologiczny (poszczególne etapy ontogenezy), psychologiczny (subiektywny sposób doświadczania trwania i przemijania), społeczny i kulturowy (podejmowanie określonych ról i obowiązków) ${ }^{12}$.

Podział życia na okresy wywodzi się z wiedzy starożytnej, rozpatrywany był przez przyrodników, lekarzy i astrologów, a także teologów, biblijnych egzegetów, filozofów. Arystoteles wskazał trzy główne fazy życia ludzkiego (młodość, wiek dojrzały i starość). Pitagoras wyróżnił w życiu człowieka cztery dwudziestoletnie odcinki i powiązał je z porami roku. Czterem odcinkom życia odpowiadają też cztery humory opisane przez Hipokratesa: dziecko jest wilgotne i ciepłe, młodzieniec jest ciepły i suchy, dorosły — suchy i zimny, starzec — zimny i wilgotny. U Celsusa i Galena żywioły (woda, ziemia, powietrze, ogień) i temperamenty (krew, żółć, flegma i wydzielina śledziony) również odpowiadają etapom życia. Z kolei astrolodzy

${ }^{10}$ Ibidem, k. A2-A2 v.

${ }^{11}$ Por. M. Kopecký, K tvorbě dvou humanistických manýristů, „Slavia” 64, 1995, s. 78; J. Kolářová, Projevy literárního manýrismu v předbělohorských moralitách, „Bohemica Olomucensia 1 - Litteraria” 2009, s. 15.

12 Por. M. Krzysztofik, Kategoria czasu antropologicznego w polskim kalendarzu XVII-wiecznym, [w:] Kalendarze staropolskie, red. I. Dacka-Górzyńska, J. Partyka, Warszawa 2013, s. 61. 
wyróżniali siedem okresów, które miały być podporządkowane kolejno wzmożonemu wpływowi siedmiu planet, któremu każdy człowiek podlega w poszczególnych fazach swej egystencji. Starożytni myśliciele także wskazywali siedem okresów życia człowieka, stanowiących odpowiedniki siedmiu dni stworzenia i siedmiu etapów istnienia. Tę ideę rozwinął św. Augustyn: w dziele Przeciwko Manichejczykom Komentarz do Księgi Rodzaju zmniejszył ilość okresów do sześciu (kolebka, dzieciństwo, wiek młodzieńczy, młodość, wiek dojrzały, starość). Początek starości wyznaczył na 60. rok życia i uznał, że może ona trwać tyle, ile pozostałe okresy sumaryczne, czyli do 120. roku życia. Podobnie jest też u Izydora z Sewili ${ }^{13}$.

W literaturze polskiej Mikołaj Rej podzielił Żywot człowieka poczciwego (1568) na trzy księgi zgodnie z arystotelesowskim schematem, ale jednocześnie porównał bieg życia ludzkiego do czterech pór roku, podobnie do Pitagorasa.

Paprocki w utworze Trínácte tabulí věku lidského nie nawiązał do żadnej z proponowanych przez dawnych myślicieli klasyfikacji okresów życia. Wyróżnił dwanaście etapów egzystencji ludzkiej, z których każdy stanowi jedną tablicę zawierającą inne zalecenia i przesłania moralne. Tablica I dotyczy narodzin, II, III i IV — dzieciństwa i wczesnej młodości, następne tablice rozpatrują konkretny wiek: V -20 lat, VI -30 lat, VII -40 lat, VIII -50 lat, IX -60 lat, X -70 lat, XI - 80 i 90 lat. Tablica XII w tytule jedynie informuje, że obejmuje ostatnie lata życia ludzkiego, ostatnia zaś - XIII rozpatruje problematykę śmierci.

Periodyzacja życia ludzkiego wprowadzona przez Paprockiego nie była jednak oryginalna. Pisarz wykorzystał i przerobił cykl dwunastu dystychów Jana Kochanowskiego pod tytułem $\mathrm{Na}$ XII tablic ludzkiego żywota, który ukazał się w pośmiertnym wydaniu Fragmentów ${ }^{14}$ sporządzonym przez Jana Januszowskiego w 1590 roku $^{15}$. Wcześniej trzy dystychy Kochanowski włączył do zbioru Fraszek, umieszczając je obok siebie, lecz opatrując osobnymi tytułami Na modość, Na starość, Na śmierć.

Kochanowski zaczyna opis dwunastu tablic życia od dwuwiersza opowiadającego o narodzinach człowieka, a zamyka wypowiedzią umierającego, który żegna się z omylnym światem. W odróżnieniu od wierszowanego utworu Kochanowskiego dzieło Paprockiego napisane jest prozą. Ponadto zawiera jedną tablicę więcej, tj. XIII, w której znalazły się rozważania na temat śmierci. Ponieważ zarówno pod względem treściowym, stylowym, jak i obiętościowym zdecydowanie różni się ona od poprzednich, Milan Kopecký wysunął hipotezę, że mogła być

13 Por. G. Minois, Historia starości. Od antyku do renesansu, przeł. K. Marczewska, Warszawa 1995, s. 128-130; J. Le Goff, N. Truong, Historia ciała w średniowieczu, przeł. I. Kania, Warszawa 2006, s. 77-79.

14 Zob. J. Kochanowski, Fraszki, oprac. J. Pelc, Wrocław 1991, s. 166-167.

15 O tym, że w dziele Paprockiego Třinácte tabuli věku lidského znalazł się przekład dystychów Kochanowskiego Na XII tablic ludzkiego żywota, nadmienił już Antonín Měšt’an, zob. idem, Kochanowski w Czechach od XVI wieku po dzień dzisiejszy, [w:] Literatura, komparatystyka, folklor. Księga poświęcona Julianowi Krzyżanowskiemu, red. J. Krzyżanowski et al., Warszawa 1968, s. 144. 
osobnym traktatem z nieznanych względów dołączonym do dzieła o dwunastu tablicach ${ }^{16}$. Potwierdzeniem tego przypuszczenia są słowa samego Paprockiego, który w dedykacji pisał: ,že jsem těchto dvanácte tabul věku lidského pod titulem Vaši Milosti na světlo vydal”"

Być może było to tylko zwykłe przejęzyczenie autora, który wzorował się na XII tablicach żywota ludzkiego. Ale prawdopodobna jest też interpretacja, że Paprocki wzmiankował w dedykacji o dwunastu tablicach, bo w nich opisał życie człowieka, XIII już go nie dotyczy, rozpatruje to, co następuje po nim — śmierć.

Podział zastosowany przez Kochanowskiego na dwanaście etapów znany jest z literatury francuskiej z drugiej połowy XIV wieku, z anonimowego poematu Les Douze Mois figurez, według którego pełny czas życia ludzkiego wynosi 72 lata i składa się z dwunastu sześcioletnich etapów odpowiadających kolejnym miesiącom w roku. Jak dowodzi Jacek Sokolski, model taki utrwalił się w partiach kalendarzowych szesnastowiecznych modlitewników związanych z tradycją ikonograficzną. Według badacza wiersze Kochanowskiego mogły być inskrypcjami przeznaczonymi do kalendarza lub też powstawały na zamówienie do jakichś obrazów ${ }^{18}$.

Paprocki już wcześniej korzystał z twórczości Jana z Czarnolasu. Na końcu II tomu Novej kratochvili ${ }^{19}$ opublikował wybór 94 fraszek, poprzedzony tytułem - Z Kochanowského, w którym zamieścił również trzy wspomniane dystychy: Na mladost člověka (Na młodość), Na starost (Na starość), Na smrt (Na śmierć). W przypadku dzieła Třinácte tabuli věku lidského Paprocki w żadnym miejscu nie wspomniał ani o Kochanowskim, ani o utworze, na którym się opierał. Nie należy się jednak temu dziwić. Pojęcie oryginału w znaczeniu dzisiejszym nie miało wówczas zastosowania, Paprocki zaś, tak jak większość autorów jego czasów, w wielu wypadkach nie tworzył dzieł nowych, lecz przerabiał obce utwory. W ten sposób ułatwiał sobie pracę, bezpośrednio przejmując gotowy szkielet obcego dzieła i wypełniał go według własnej inwencji, zgodnie z oczekiwaniami kulturowymi i obyczajowymi potencjalnych czytelników.

Na początku każdej z dwunastu tablic dzieła Paprockiego jest tytuł wskazujący wiek, którego dotyczy, a następnie znajduje się dwuwiersz z Kochanowskiego (przetłumaczony dosłownie), pełniący funkcję motta do rozwijanych treści, np.

Deváta tabule věku člověčího, kteráž se tkne člověka již šestdesáte let majícího.

Někdo má zlato, má perli i šaty,

Ale kdo na svým přestal ten bohatý ${ }^{20}$.

${ }^{16}$ Por. M. Kopecký, op. cit., s. 78.

17 B. Paprocký, Tŕinácte tabulí..., k. A3 v.

18 Por. J. Sokolski, Cursus aetatis. O cyklu „Na XII tablic ludzkiego żywota” Jana Kochanowskiego, „Roczniki Humanistyczne” LVI, 2008, z. 1, s. 93-107.

19 Por. B. Paprocký, Jiná částka nové kratochvile...

${ }^{20}$ B. Paprocký, Tŕinácte tabulí..., k. D2 v. Por. z IX tablicą u Kochanowskiego: „Nie kto ma złoto, ma perły, ma szaty/ Ale kto na swym przestał, to bogaty”, [w:] J. Kochanowski, op. cit., s. 167. 
Należy również zwrócić uwagę, że do każdej tablicy została przypasowana rycina z symbliką zwierzęcą. Poszczególnym etapom życia przypisano inne zwierzę: dzieciństwu - małpę, wiekowi młodzieńczemu — cielę, latom dojrzałym - lwa, byka, lisa itd. Na XII tablicy, odnoszącej się do finalnej fazy życia, widnieje łabędź utożsamiany $\mathrm{z}$ wierzchowcem umarłych i będący jednym (obok łodzi funeralnej oraz harfy) z symboli mistycznej podróży w zaświaty ${ }^{21}$.

Paprocki postrzega starość jako odrębny okres życia, który zaczyna się w wieku 60 lat, stanowiący swego rodzaju granicę między tym, co było, a tym, co będzie. Uświadamia czytelnikowi, że jest to czas, kiedy kończy się pierwsza część ziemskiej wędrowki pełna wszelakich uciech i rozkoszy doczesnych. Druga część życia, która pozostała, powinna koncentować się wyłącznie na myśleniu i działaniu pomocnym w osiągnięciu zbawienia wiecznego:

Z př́ičiny té, nic jiného nemá přemejšleti mysl jeho, jednom kterak by druhou částku života svého v pobožnosti vykonal, nad hříchy v mladosti spáchanými želel, a toho litoval, že v nich své měl oblíbení, a zanechal skutky Pánu Bohu milé a př́ijemné, vždy k němu volajíce o smilování, ne tak ústy jako srdcem² ${ }^{22}$.

Człowiek na każdym etapie egzystencji ma swoje prawa i obowiązki. Paprocki mówi o powinnościach ludzi starych, powielając zakorzenione w kulturze chrześcijańskiej przekonanie o starości jako o czasie przygotowania na śmierć. Starcowi nie pozostaje nic innego, jak: pamięć o sądzie ostatecznym, myśl skierowana w stonę chwały bożej, tłumienie pragnień doczesnych: „Volej, dokavádž se Pán nesmiluje nad tebou, všeliké tvé myšlení necht' jinam nesměřuje, jednom ke cti a chvále Boží, necht' pomije žádost věci zemských"23.

Starość w utworze Třinácte tabuli věku lidského występuje w opozycji do młodości, utożsamiana jest $\mathrm{z}$ inercją, słabością, niemocą. Starzec powinien wycofać się z dotychczasowego aktywnego życia, odsunąć się na plan dalszy, ustąpić miejsca młodemu pokoleniu. Ponadto ma go cechować skromny wygląd, bez zbytecznego przepychu: „Zanechej frejův starče, nespomínej na tance, odvrž nádherné šaty, postup mladým místa, slož z sebe řetězy, odevzdej armpanty a prsteny"24.

Mimo wyraźnego w dziele Paprockiego imperatywu pogodzenia się ze starością: ,[...] musíš zanechati věci mladosti přináležející, musíš opustiti freje, žerty i hry $[\ldots]^{\prime 25}$, mimo nawoływania narratora do odwrócenia myśli od świata doczesnego i skierowania się w stronę Boga: ,[...] tobě náleží to vše, cožby ke cti a chvále boží býti mohlo, činiti [...]"26, wyczuwalna zdaje się być tęsknota za utraconą na zawsze młodością: ,[...] ještě mladým se rovnat ve všem chtějí, ačkoli jim to právě neslušs'” ${ }^{27}$. Paprocki uzmysławia czytelnikowi, że świadomość

\footnotetext{
${ }^{21}$ Por. J. E. Cirlot, Stownik symboli, przeł. I. Kania, Kraków, s. 239.

${ }^{22}$ B. Paprocký, Třinácte tabulí..., k. D3.

23 Ibidem, k. D4-D4 v.

${ }^{24}$ Ibidem, k. E.

${ }^{25}$ Ibidem, k. E v.

${ }^{26}$ Ibidem, k. E-E v.

${ }^{27}$ Ibidem, k. E.
} 
przemijania, niemożność zatrzymania czasu jest dla wielu starszych ludzi bardzo bolesna i trudna do zaakceptowania: „Nachází se to obyčejně při lidech již věkem sešlých, že se náramně v hněvu rozněcují, když starý jejich věk předkládan býva, neb jím velmi jest věc př́ikrá viděti již smrt před očima"28.

Jak zauważyła Małgorzata Krzysztofik:

Niezależnie od wszelkich prób pochwały starości, budowanych na płaszczyźnie etycznej i filozoficznej, kontemplacja estetyczna prowadzi do wniosków pesmistycznych, stąd częsty w literaturze motyw przemijania urody, niejednokrotnie ukazany na zasadzie kontrastu (młodość-starość) ${ }^{29}$.

Paprocki w swoim dziele również zawarł ten negatywny aspekt ostatniej fazy ontogenezy. Nakreślił realistyczny obraz starczej fizjonomii, fizyczny rozpad niegdyś atrakcyjnego ciała: „...již všecko tělo starostí vadne, když oči zrak potracují, uši sluchu nemají, když tváŕ bledne, zuby hnijí, kůže se krčí, ústa zapáchají, prsy duch volně nevypouští, kolena se třesou, nohy tížnost těla zdržeti nemohou"30.

Ale nie tylko pogarszający się wygląd stanowi problem dla ludzi starych, także malejąca z wiekiem sprawność umysłowa: „...rozum ten, kterýž již př́i sešlosti své nic chvalítebného vykonati nemůže..."31.

Utrwalony w tradycji literackiej motyw starca mentora, przewodnika młodych pojawia się u Paprockiego w rozdziale traktującym o latach młodzieńczych. Zawarta jest tam też wskazówka, że starość to czas czerpania z nawyków przyswojonych w młodości: „...čehož se přidržel v mladosti, téhož se přidrží i až do starosti..." ${ }^{32}$.

Każdy człowiek pragnie doczekać starości, nie zważając na negatywne aspekty, jakie z sobą niesie. Myśl tę zawarł Jan Kochanowski w XI dystychu Fragmentó $^{33}$, który Paprocki wykorzystał jako motto do tablicy XI:

Mizerná starost, všichni tě žádáme,

Ale když přijdeš, na tě naříkáme ${ }^{34}$.

Doświadczenie pełni istnienia domaga się przeżycia wszystkich faz ontogenezy i nawet starość — ostatni najokrutniejszy etap — ma swoją wartość — ponieważ jest dopełnieniem miary życia. Bez starości ziemskie istnienie człowieka byłoby w jakimś stopniu niepełne ${ }^{35}$.

28 Ibidem.

${ }^{29}$ M. Krzysztofik, Czas życia jako paradygmat kultury (starość). Stanisław Kołakowski „Wiek ludzki” (1584); Jan Protasowicz „,Konterfet czlowieka starego” (1597), „Ruch Literacki” 2012, z. 6, s. 687.

${ }^{30}$ B. Paprocký, Třinácte tabulí..., k. E v.

31 Ibidem.

32 Ibidem, k. C.

33 J. Kochanowski, op. cit., s. 167.

${ }^{34}$ B. Paprocký, Tŕinácte tabulí..., k. D4 v.

35 Por. M. Krzysztofik, Czas życia..., s. 691. 
Starość dla Paprockiego jest okresem oczekiwania na śmierć i właściwego przygotowania do chwili odejścia, która nieuchronnie się zbliża. Nie ma strachu przed śmiercią, lęk neutralizuje wizja życia wiecznego w Królestwie Niebieskim.

Obraz starości wyłaniający się z utworu Třinácte tabuli véku lidského w najmniejszym stopniu nie koresponduje z wizją ,jesieni życia” znaną Polakom z Żywota człowieka poczciwego Mikołaja Reja, w którym starzec w pełni akceptuje swój stan i korzysta z „pociech rozlicznych”. I mimo że Paprocki niejednokrotnie nawiązywał do twórczości Reja, w przypadku postrzegania starości diametralnie się od niego różni.

Karel Krejčí stwierdził, że Trúnácte tabuli věku lidského stanowi rozrachunek pisarza $\mathrm{z}$ własnym życiem. W opisie kolejnych etapów ludzkiej egzystencji prezentowanych w poszczególnych tablicach można dostrzec analogię do bogatego w doświadczenia życia Paprockiego, który, jak pisze badacz czeski:

prošel obdobím bujného vzepětí sil renesance, nádherou humanistického dvora královského, bojiští v různých končinách Evropy, vášní osobní ctižádosti i nenávistí rozpoutaného boje stranického, trpkou školou emigrace i fanatismem boje náboženského a své životní dílo končil uprostřed temné atmosféry vznikajícího baroka ${ }^{36}$.

Paprocki tworzył swoje dzieło w wieku 60 lat, dlatego też w opisie starości zdaje się słychać dwugłos narratora i autora, który sam, nie bez żalu, zbliżał się do kresu swej ziemskiej wędrówki.

\section{Bibliografia}

Cirlot J.E., Słownik symboli, przeł. I. Kania, Kraków.

Kochanowski J., Fraszki, oprac. J. Pelc, Wrocław 1991.

Koczur-Lejk K., Bartlomiej Paprocki - piśmiennictwo i przekład. W stronę kontrreformacji, Szczecin 2014.

Koláŕová J., Projevy literárního manýrismu v předbělohorských moralitách, „Bohemica Olomucensia 1 - Litteraria" 2009.

Kopecký M., K tvorbě dvou humanistických manýristi̊, „Slavia” 64, 1995.

Krejčí K., Bartoloměj Paprocki z Hlohol a Paprocké Vůle. Život - dilo - forma a jazyk, Praha 1946.

Krzysztofik M., Czas życia jako paradygmat kultury (starość). Stanisław Kołakowski ,Wiek ludzki” (1584); Jan Protasowicz „Konterfet człowieka starego” (1597), „Ruch Literacki” 2012, z. 6 .

Krzysztofik M., Kategoria czasu antropologicznego w polskim kalendarzu XVII-wiecznym, [w:] Kalendarze staropolskie, red. I. Dacka-Górzyńska, J. Partyka, Warszawa 2013.

Le Goff J., Truong N., Historia ciała w średniowieczu, przeł. I. Kania, Warszawa 2006.

${ }^{36}$ K. Krejčí, Bartoloměj Paprocki z Hlohol a Paprocké Vưle. Život - dílo-forma a jazyk, Praha 1946, s. 183. 
Měštan A., Kochanowski w Czechach od XVI wieku po dzień dzisiejszy, [w:] Literatura, komparatystyka, folklor. Księga poświęcona Julianowi Krzyżanowskiemu, red. J. Krzyżanowski et al., Warszawa 1968.

Minois G., Historia starości. Od antyku do renesansu, przeł. K. Marczewska, Warszawa 1995.

Paprocký B., Jiná částka nové kratochvíle, s kterouž bohyně Venus na svět vyšla, pět set žertův i jiných kratochvilných přikladi̊v s sebou vede. $Z$ rozličných př̉běhưv sebrané a nově vydané, v Starém Městě pražském u Daniele Sedlčanského, 1598.

Paprocký B., Kšaft, jenž byl od jednoho starce učiněn třem synům nepořádně se chovajicím tak aby nejhorší z nich v statku jeho nedědil. Pročež oni dali se v soud, jedenkaždý, aby dědicem zůstal po otci, skutky své schvalujic a druhého zlehčujic. Z čeho jedenkaždý naučit se müže, jak se má vystřihat marnosti, v Praze u J. Šumana, 1601.

Paprocký B., Kvalt na pohany ke všem křestanským panům, králům i knižatům a zvláště nejpřemoženějšího královstvi polského obojím stavưm duchovnímu i světskému učiněný, bez miejsca wydania 1595.

Paprocký B., Panna, v Starém Městě pražském u Jana Šumana, 1602.

Paprocký B., Rozmlouváni kolátora s farářem velmi pěkné, každému křestianskému člověku užitečné. Nyni v nově sepsané a vydané, v Brně u Bartoloměje Albrechta Formana, 1607.

Paprocký B., Štambuch slezský, v kterém hospodař s hostem o mnohých věcech spasitedlných rozpravuji, pod erby a rody starodavných pánuv, pánův a rytírstva knižetství horních v Slezí, v Brně u Bartoloměje Albrechta Formana, 1607.

Paprocký B., Testament starca jednego, który miat trzech synów: z których jeden pijaństwem, drugi nierządna miłościa, trzeci się kosterstwem bawit. Tych nie mogąc już w niemocy inaczej skarać, rozkazal, aby gorszy z nich $w$ dobrach jego po śmierci nie dziedziczyt. Nowo z łacińskiego języka na polski przełożony, w Krakowie u Mateusza Siebeneychera, 1578.

Paprocký B., Trinácte tabuli věku lidského krátce sepsaných, v Starém Městě pražském u Jana Šumana, 1601.

Sokolski J., Cursus aetatis. O cyklu „Na XII tablic ludzkiego żywota” Jana Kochanowskiego, „Roczniki Humanistyczne” LVI, 2008, z. 1.

\section{Old age as a stage of life in the work by Bartholomew Paprocki Třinácte tabuli věku lidského}

\section{Summary}

Bartholomew Paprocki in his work Třinácte tabuli věku lidského (1601) describes stages of human existence. Each stage constitutes one "board" in which Paprocki contains different moral messages. On individual "boards" the writer scrutinizes birth, childhood, youth, adulthood, old age. Paprocki perceives old age as the final stage of life, starting at the age of 60 , which is a boundary between what happened and what will happen. The first part of human life is over and the rest should be devoted to religious worship, when one regrets sins committed in young age and begs God for forgiveness.

Keywords: old age, ontogenesis, Czech literature of the 17th century, christian culture 


\section{Stáří jako etapa života v díle Bartoloměje Paprockého Třinácte tabuli věku lidského}

\section{Obsah}

Bartoloměj Paprocký ve svém díle Třinácte tabuli věku lidského (1601) popisuje etapa lidského života. Každé období je jedna „tabule”, ve které Paprocký dává jiné morální napomenutína základě citátů z antických spisovatelů a církevních otců. V jednotlivých „tabulích” autor charakterizuje dětství, mládí, dospělost a stárí. Paprocký považuje stáří za poslední etapu života, jež začíná ve věku 60 let, který znamená hranici mezi tím, co bylo, a tím, co bude. První částka života končí, v druhé částce je třeba žít zbožně, litovat hříchů spáchaných v mládí a prosit Boha o smilování.

Klíčová slova: stárí, ontogeneze, česká literatura 17. století, křest’anská kultura 